\section{SOME HYDROIDS (CNIDARIA: HYDROZOA: HYDROIDOLINA) FROM THE KONKAN COAST, MAHARASHTRA, INDIA}

\section{Pooja Nagale ${ }^{1} \&$ Deepak Apte ${ }^{2}$}

1,2 Bombay Natural History Society, Hornbill House, Opp. Lion Gate, Dr. Salim Ali Chowk, Shaheed Bhagat Singh Road, Mumbai, Maharashtra 400001, India ${ }^{1}$ poojanagale@gmail.com (corresponding author), ${ }^{2}$ spiderconch@gmail.com

Hydroids from intertidal regions on the coast of India have received only modest attention. The eminent Indian hydrozoan taxonomist T.A. Mammen (1963, $1965 a, b)$ recorded and described a number of shallowwater species from southern India. Venugopalan \& Wagh $(1986,1990)$ recorded a few fouling hydroids from Mumbai harbor, including the predominantly intertidal sertulariid Dynamena crisioides. In Maharashtra State Gazetteers (1974-1975), only Pennaria disticha and Ectopleura viridis (as Tubularia pacifica) were reported, both with minimal information, and more detailed descriptions of them are warranted. Finally, several intertidal hydroid species were recorded from Okhamandal, in the state of Gujarat (Thornely 1916).

Intertidal hydroids of the Konkan coast have been neglected, although the region has ample intertidal habitat and moderate faunal diversity. Objectives of the present paper were to explore the benthic hydrozoan fauna of Konkan, and to provide some details of their morphological characters.

Taxonomic and morphological studies were undertaken to identify the various hydroid colonies that were collected. Eight species, collected from eight different sampling sites (Table 1), are reported herein. These are referable to the anthoathecate families Pennariidae (1 species) and Tubulariidae (1 species), and to the leptothecate families Aglaopheniidae (1 species), Sertulariidae (4 species), and Campanulariidae (1 species).

Our study was undertaken on the rocky shores of the Konkan coast, Maharashtra, a region facing the Arabian Sea on the western coastline of India. Hydroids were collected from Ratnagiri (Mandavi, Mirya, Aare Ware, Undi, Purngad), Rajapur (Ambolgad, Kasheli) and Vijaydurga (Image 1). Specimens were collected manually, during low tide, from rock pools and rock crevices. Identification of species was based on morphological characters of hydroid, like colony form, arrangement of hydrocladia and hydrotheca, polyp morphology and gonophore. Most were preserved directly in $4 \%$ formalin in sea water for further study, while some were studied alive. Collections were examined microscopically using a stereoscope (Leica EZ4 D) and a compound microscope (Leica DM750). Drawings and photomicrographs prepared in the laboratory were also used in establishing morphological characters of the hydroids. All specimens were deposited in the collections of the Bombay Natural History Society (BNHS), Maharashtra.

\section{Family: Pennariidae McCrady, 1859}

\section{Pennaria disticha Goldfuss, 1820}

Material studied: size 2-20 cm, BNHS-HY-0047, BNHS-HY-0084, BNHS-0095, BNHS-HY-0096 (Images 2 $A-C)$.

Substrate: Rocks; colonies also observed encrusting

DOI: http://dx.doi.org/10.11609/JoTT.o3484.4814-8 | ZooBank: urn:Isid:zoobank.org:pub:4388D472-ACC4-41CF-AA73-AE391B160289

Copyright: @ Nagale \& Apte 2013. Creative Commons Attribution 3.0 Unported License. JoTT allows unrestricted use of this article in any medium, reproduction and distribution by providing adequate credit to the authors and the source of publication.

Funding: None.

Competing Interest: Authors declare no competing interest.

Acknowledgements: We are grateful to Mr. Vishal Bhave and Ms. Amruta Prasade for invaluable assistance and contributions in curating the collections. Thanks are also due to Mr. Vishwas Shinde and Mr. Rajendra Pawar for help in the field. We acknowledge the Director of the Bombay Natural History Society for support and encouragement of our studies. 


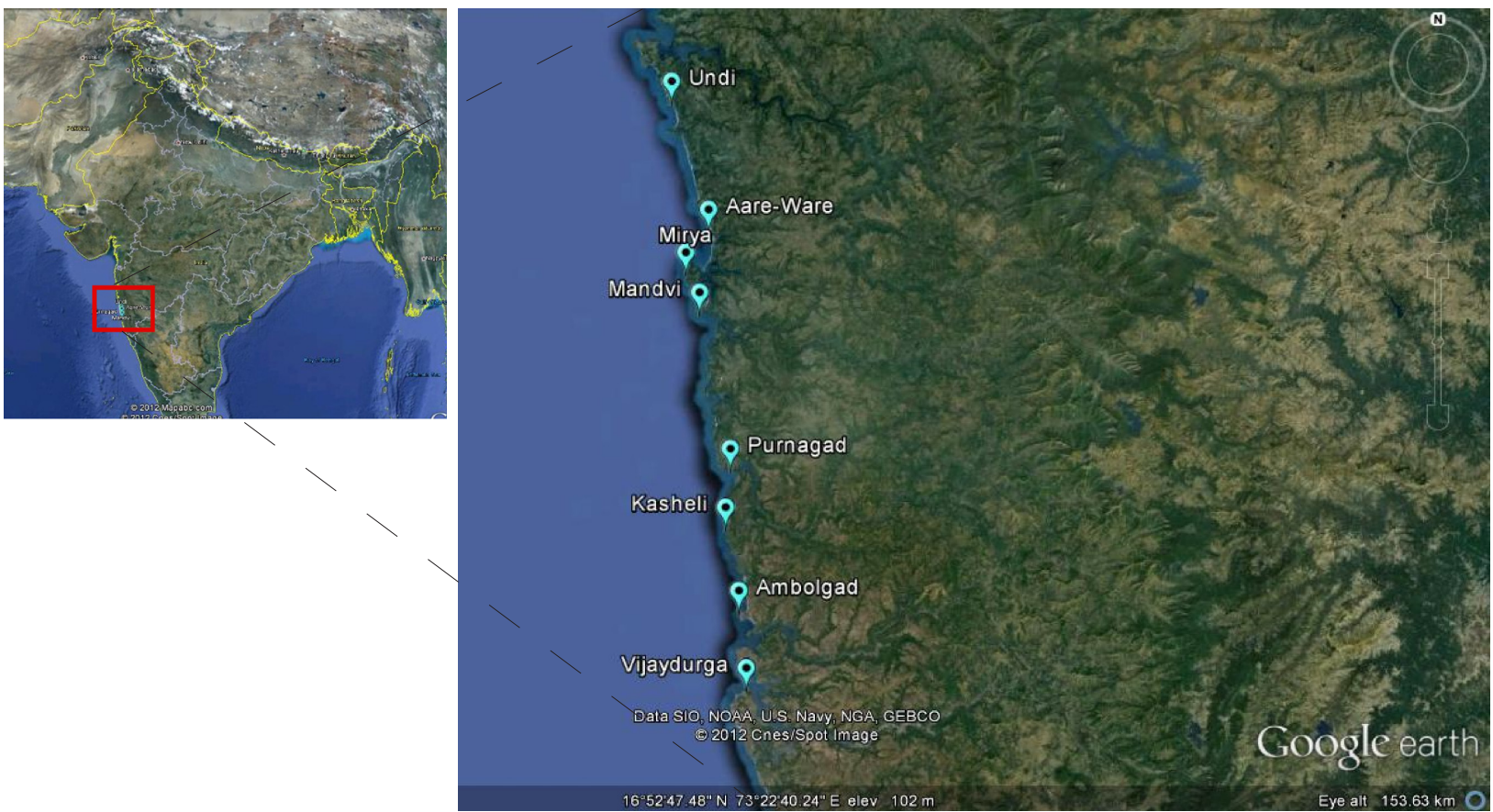

Image 1. Collection sites along Konkan coast, Maharashtra. (Courtesy: Google Earth)

Table 1. Distribution of hydroids along various coasts of Ratnagiri

\begin{tabular}{|c|c|c|c|c|c|c|c|c|}
\hline Species Name/Site & Mandavi & Mirya & Aare-Ware & Undi & Purnagad & Ambolgad & Kasheli & Vijaydurga \\
\hline Pennaria disticha Goldfuss, 1820 & $*$ & * & * & * & * & * & * & * \\
\hline Ectopleura viridis (Pictet, 1893) & * & * & & & * & & & \\
\hline Macrorhynchia philippina Kirchenpauer, 1872 & $*$ & $*$ & & * & & $*$ & $*$ & \\
\hline Dynamena crisioides Lamouroux, 1824 & * & * & * & * & & * & * & * \\
\hline Dynamena sp. (Linnaeus, 1758) & * & * & & * & & * & * & \\
\hline Dynamena quadridentata (Ellis \& Solander, 1786) & * & $*$ & & & & & $*$ & \\
\hline Idiellana pristis (Lamouroux, 1816) & * & & & $*$ & & $*$ & $*$ & \\
\hline Obelia geniculata (Linnaeus, 1758) & & & & & & & & * \\
\hline
\end{tabular}

* - present

sponges.

Colony characters: Colony erect, pinnate, arising from a creeping hydrorhiza. Hydrocaulus branched (Image 2B), with alternate hydrocladia; hydrocladia and hydranth pedicels annulated basally; Hydranths pearshaped, with a proximal whorl of 8-10 filiform tentacles (Image 2C) and distal whorls of shorter capitate tentacles; Medusa buds present on some colonies (Image 2C).

Known distribution from India: Pamban and Neendakara (Mammen 1963)

Family: Tubulariidae Goldfuss, 1818

\section{Ectopleura viridis (Pictet, 1893)}

Material studied: size 1-4 cm, BNHS-HY-0036, BNHS-
HY-0042, BNHS-HY-0093, (Image 2 D-F).

Substrate: Rockpool; rock crevices, encrusting sponges.

Colony characters: Hydroids growing in clusters (Image 2D); hydrocaulus unbranched, long, tubular (Image 2E). Hydranths vasiform, with single whorl of 10-16 aboral filiform tentacles and single whorl of 1518 oral tentacles. Medusa buds (7 fertile hydranths) present at base of aboral tentacles (Image $2 \mathrm{E}-\mathrm{F}$ ).

Known distribution from India: Neendakara, Thankassery and Madras harbor (Mammen 1963) and Pamban (Gravely 1927).

Family: Aglaopheniidae Marktanner-Turneretscher, 1890 


\section{Macrorhynchia philippina Kirchenpauer, 1872}

Material studied: size up to $6 \mathrm{~cm}$, BNHS-HY-0035, BNHS-HY-0081, BNHS-HY-0113, (Image 2 G-I).

Substrate: Rockpool, in a shaded area.

Colony characters: Colony erect, pinnate, with some colonies multipinnate. Hydrocaulus branched, with alternate, unbranched hydrocladia (Image $2 \mathrm{H}$ ). Hydrothecae borne on upper surface of hydrocladia, with up to 17 per hydrocladium. Hydrothecae sacshaped (Image 2 I). Hydranths with 8-10 tentacles. Other characters of the hydroid correspond with material described by Schuchert (2003).

Known distribution from India: Pamban (Mammen 1965b; Gravely 1927), Andaman (Ritchie 1910) and Adatra (Thornely 1916).

\section{Family: Sertulariidae Lamouroux, 1812}

\section{Dynamena crisioides Lamouroux, 1824}

Material studied: size 8-25 mm, BNHS-HY-0067, BNHS-HY-0071, (Image $3 \mathrm{~A}-\mathrm{C}$ ).
Substrate: Shaded rocky areas, including rock crevices and overhangs in rockpools.

Colony characters: Hydrocladial arrangement alternate (Image 3A); hydrothecae subopposite, tubular, slender, facing outwards, margin with three cusps (Image $3 C)$; operculum of two flaps closing orifice. Gonothecae vase-shaped, attached to base of hydrothecae (Image 3B). Orifice of gonotheca circular, with flat operculum.

Known distribution from India: Krusadai Island, south coast (Mammen 1965a), Mumbai (Venugopalan \& Wagh 1986)

\section{Dynamena sp.}

Material studied: size 2-5 mm, BNHS-HY-0069, (Image $3 \mathrm{D}-\mathrm{F}$ ).

Substrate: Brown algae (Sargassum sp.).

Colony characters: Hydroid colony epiphytic, growing on both sides of algal thallus (Image 3D). Hydrocaulus erect, monosiphonic, arising from a stolonal hydrorhiza. Hydrothecae opposite (Image 3E); hydrothecal pairs
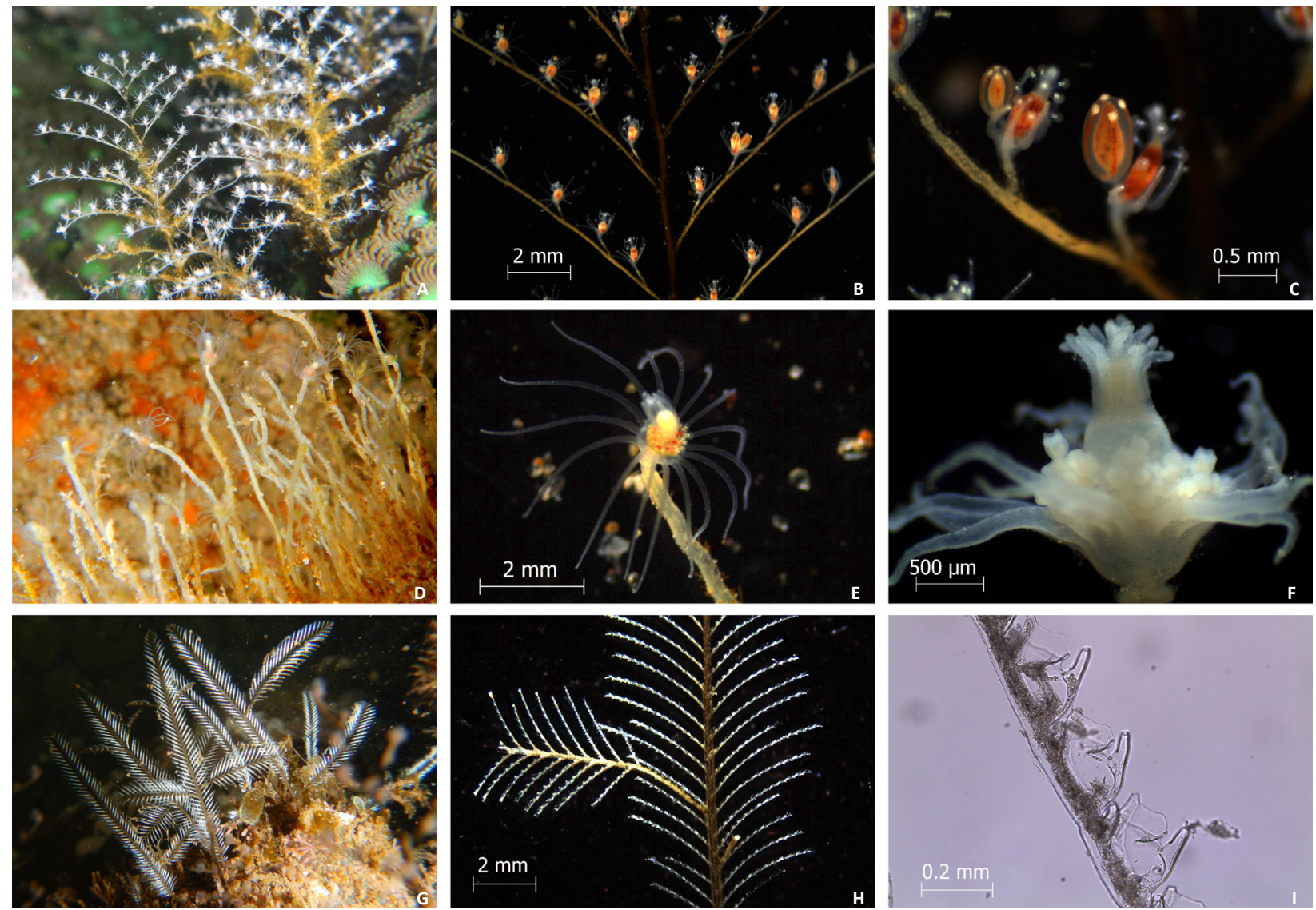

Image 2. Pennaria disticha (A) Colonies in the rockpool, (B) Arrangement of hydrocladia, (C) Hydranth with budding medusae; Ectopleura viridis (D) Colonies in the rock pool, (E) Hydranth (before preservation), (F) Hydranth (after preservation) showing arrangement of tentacles in two whorls and presence of medusa buds; Macrorhynchia philippina (G) Colonies in the rock pool, (H) Arrangement of hydrocladia, (I) Hydrotheca. (C) Pooja Nagale 



Image 3. Dyanamena crisioides (A) Arrangement of hydrocladia, (B) Gonotheca, (C) Arrangement of hydrotheca; Dynamena sp. (D) Epiphytic colonies on algae, (E-F) Arrangement of hydrotheca; Dynamena quadridentata (G) Epiphytic colonies spread over algae, $(\mathrm{H})$ Arrangement of hydrothecal pairs, (I) Barrel shaped gonotheca. (C Pooja Nagale

adnate, with orifice opening outwards. Hydranth retracted (Image 3F). Gonothecae absent.

Known distribution from India: Not yet known.

\section{Dynamena quadridentata (Ellis \& Solander, 1786)}

Material studied: size $1.5-5 \mathrm{~mm}$, BNHS-HY-0083, (Image 3 G-I).

Substrate: Epiphytic on green algae (possibly Ulva sp.) and red algae (Gracilaria sp.).

Colony characters: Colony unbranched, creeping on algae (Image 3G). Each hydrocaulus with 3-4 pairs of hydrothecae (Image $3 \mathrm{H}$ ). Number of hydrothecal pairs differing from base to tip, with 1-4 sequentially. Other characters similar to description of Mammen (1965a). Gonothecae vase- or barrel-shaped, with annulations, arising from hydrocaulus at base of first pair of hydrothecae. Orifice of gonotheca round, with single, flat operculum (Image 3I).

Known distribution from India: Gulf of Mannar, Thankassery, Cape Comorin and Kovilam (Mammen 1965a)
Idiellana pristis (Lamouroux, 1816)

Material studied: size up to $6 \mathrm{~cm}, \mathrm{BNHS}-\mathrm{HY}-0018$, BNHS-HY-0019, BNHS-HY-0066, BNHS-HY-0082, BNHSHY-0090, (Image 4 A-C).

Substrate: Rock, sometimes encrusting sponges.

Colony characters: Colony erect, pinnate. Hydrocaulus monosiphonic, arising from creeping hydrorhiza. Hydrocladia unbranched, alternately arranged (Image 4A). Hydrothecae tubular, curved outwards; alternate and adjoining to each other (Image 4B). Female gonothecae present; urn-shaped; on hydrocaulus and hydrocladia (Image 4C).

Known distribution from India: Gulf of Mannar (Mammen 1965a), Konkan coast (Armstrong 1879), Dwarka and Poshitra (Thornely 1916)

\section{Family: Campanulariidae Johnston, 1836}

\section{Obelia geniculata (Linnaeus, 1758)}

Material studied: size 4-10 mm, BNHS-HY-0153, (Image $4 \mathrm{D}-\mathrm{F}$ ).

Substrate: Rock with sand; also creeping on green 

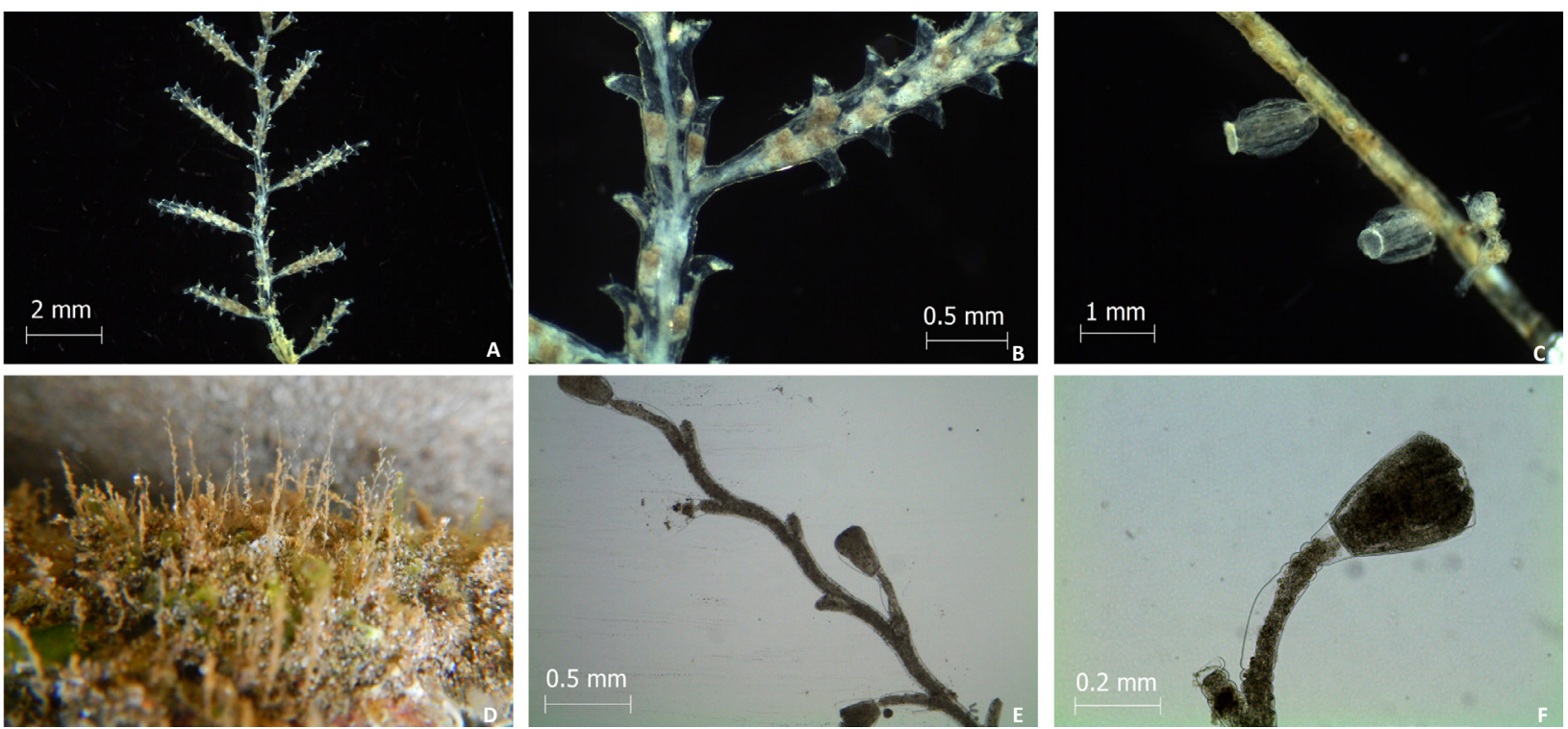

Image 4. Idiellana pristis (A) Arrangement of hydrocladia, (B) Arrangemant of hydrotheca on both hydrocaulus and hydrocladia, (C) Gonotheca; Obelia geniculata (D) Minute colonies in shaded area, (E) Geniculate hydrocaulus, (F) Polyp. C Pooja Nagale

algae.

Colony characters: Colony erect, branched or unbranched; arising from a creeping stolon. Hydrocaulus zigzag (geniculate) in form (Image 4E). Internodes annulated proximally. Hydrothecae bell-shaped; margin entire (uncusped) (Image 4F).

Known distribution from India: No specific reference found for locality.

The present study is noteworthy in that five species are recorded for the first time from Maharashtra. Moreover, all eight species reported herein constitute new records for the Konkan coast. Hydroids were well-represented at every site except Vijaydurga. Dynamena sp. requires more study because of the absence of gonothecae in our specimens. It was assigned to sertulariid genus on the basis of hydrothecal arrangement and structure. Pennaria disticha and Dynamena crisioides were the most common species at sites along the coast. Although $P$. disticha and Ectopleura viridis were reported in the state faunal series, Gazetteer of Maharashtra, we provide a more detailed description and have added specific collection locales. All species collected here are from rocky shores and there is a need to further explore these habitats.

\section{REFERENCES}

Gravely, F.H. (1927). The littoral fauna of Krusadai island in the Gulf of Manaar. Hydrozoa. Bulletin of Madras Government, Museum of Natural History Society 1: 7-20.

Maharashtra State Gazetteers (1974-1975). General series: Fauna. The Director, Government Printing, Stationary, Maharashtra State, Bombay, (175-176) 707pp+5pls.

Mammen, T.A. (1963). On a collection of hydroids from South India. I. Suborder Athecata. Journal of the Marine Biological Association of India 5(1): 27-61.

Mammen, T.A. (1965a). On a collection of hydroids from South India. II. Suborder Thecata (excluding family Plumulariidae). Journal of the Marine Biological Association of India 7: 1-57.

Mammen, T.A. (1965b). On a collection of hydroids from South India. III. Suborder Thecata (family Plumulariidae). Journal of the Marine Biological Association of India 7(2): 291-324.

Ritchie, J. (1910). The hydroids of the Indian museum. Records of Indian museum (Calcutta) (5): 1-30.

Schuchert, P. (2003). Hydroids (Cnidaria, Hydrozoa) of the Danish expedition to the Kei Islands. Steenstrupia 27(2): 137-256.

Thornely, L.R. (1916). Report on the hydroida collected by Mr. James Hornell at Okhamandal in Kattiawar in 1905-6, pp. 147-150. In: Hornell J. (ed.). Report to the Government of Baroda on the marine zoology of Okhamandal in Kattiawar, Part II. Williams \& Northgate, London.

Venugopalan, V.P. \& A.B. Wagh (1986). A note on the fouling hydroids from the offshore waters of Bombay. Mahasagar- Bulletin of National Institute of Oceanography 19(4): 275-277. 